\title{
Stability of adenine-based cytokinins in aqueous solution
}

\author{
David S. Hart ${ }^{1}$ - Andrew Keightley ${ }^{2}$ - Daryl Sappington ${ }^{1}$ Phuong T. M. Nguyen ${ }^{1}$ • \\ Charleen Chritton $^{1} \cdot$ Gary R. Seckinger $^{1} \cdot$ Kenneth C. Torres $^{1}$
}

Received: 6 August 2014 / Accepted: 19 November 2015 / Published online: 4 February 2016 / Editor: David Duncan

(C) The Author(s) 2016. This article is published with open access at Springerlink.com

\begin{abstract}
Since the isolation of the first cytokinin almost $60 \mathrm{yr}$ ago, cytokinins have become critically important for ornamental and agricultural crops in plant tissue culture. Despite the extensive research on this class of compounds, little information is available on the chemical stability of cytokinins in solution or following an autoclave cycle with Murashige and Skoog (MS) basal medium. This work describes the stability in aqueous solutions of five widely used adenine-based cytokinins: trans-zeatin (tZ), 6-( $\gamma, \gamma$-dimethylallylamino) purine (2iP), kinetin, benzyladenine (BA), and $m$-topolin. High pressure liquid chromatography (HPLC) and electrospray ionization-mass spectrometry (ESI-MS) were used to quantify and identify their degradation. BA, kinetin, $2 \mathrm{iP}$, and $m$-topolin were stable at $1.0 \mathrm{mg} \mathrm{mL}^{-1}$ in $0.05 \mathrm{~N} \mathrm{KOH}$, with no statistically significant concentration changes $(p>0.05)$ after $90 \mathrm{~d}$ of storage at temperatures of $-20^{\circ} \mathrm{C}, 2-6^{\circ} \mathrm{C}$, or $25^{\circ} \mathrm{C}$. The cytokinin $\mathrm{tZ}$ was used as a model compound to evaluate stability under alkaline and acid conditions as well as after repeated freeze-thaw cycles. Trans-zeatin retained $>90 \%$ of the initial concentration of $1.0 \mathrm{mg} \mathrm{mL}^{-1}$ when dissolved in $0.01 \mathrm{~N} \mathrm{KOH}$ and stored at $-20^{\circ} \mathrm{C}$ and $2-6^{\circ} \mathrm{C}$ for $90 \mathrm{~d}$, with only the $2-6^{\circ} \mathrm{C}$ temperature treatment showing a statistical significant concentration change $(p=0.03)$. The $1.0 \mathrm{mg} \mathrm{mL}^{-1}$ tZ solution in
\end{abstract}

Electronic supplementary material The online version of this article (doi:10.1007/s11627-015-9734-5) contains supplementary material, which is available to authorized users.

David S. Hart

david@phytotechlab.com

1 PhytoTechnology Laboratories, 9245 Flint Street, Overland Park, KS 66214, USA

2 Biological Mass Spectrometry and Proteomics Facility, University of Missouri at Kansas City, Kansas, MO 64110, USA
$0.01 \mathrm{~N} \mathrm{KOH}$ was stable through six repeated freeze-thaw cycles over $90 \mathrm{~d}$ without any significant change in concentration compared to the initial freeze-thaw. Yet, $t Z$ showed highly significant concentration changes when dissolved at $50 \mathrm{mg} \mathrm{mL}^{-1}$ and $0.5 \mathrm{~N} \mathrm{KOH}$. All of these adenine-based cytokinins showed exceptional stability following an autoclave cycle at $121^{\circ} \mathrm{C}, 110 \mathrm{kPa}$ for $30 \mathrm{~min}$ when in solutions of $1.0 \mathrm{mg} \mathrm{mL}^{-1}$ in $0.05 \mathrm{~N} \mathrm{KOH}$, with no significant degradation detected. Trans-zeatin was also found to be stable after one autoclave cycle with $1 \times$ MS-basal salts.

Keywords Cytokinin $\cdot$ Stability $\cdot$ HPLC $\cdot$ FTIR $\cdot$ Mass spectrometry

\section{Introduction}

Cytokinins are a class of plant-growth regulators that were discovered because of their ability to enhance cell division in plant-tissue culture (Miller et al. 1955). Since the discovery of cytokinins, their disruption of apical dominance (Wickson and Thimann 1958), their biosynthesis from tRNA (Skoog and Armstrong 1970; Letham and Palni 1983) and de novo (Takei et al. 2001; Takei et al. 2004), as well as their role in plant development (Werner et al. 2003; Besnard et al. 2014) and signal transduction (Kakimoto 1996; Brandstatter and Kieber 1998; Hwang and Sheen 2001) have become welldefined processes. The use of cytokinins for the maintenance of the shoot apical meristem (Shani et al. 2006), and their in vivo metabolism (Mok and Mok 2001) in general have also become better understood. In spite of our knowledge of these processes at the cellular level, little is known about the chemical stability of cytokinins in solution or their physical stability during storage or an autoclave cycle. Though some phenylurea derivatives (e.g., thidiazuron, 4-CPPU) display 
cytokinin activity (Mok et al. 2005), they do not occur naturally, whereas some adenine-based cytokinins do occur naturally. Adenine-based cytokinins also represent the majority of cytokinins commercially sold.

Cytokinins promote cell division, shoot organogenesis, and shoot proliferation over time. The resultant reduction in production scale-up time is why cytokinins have become so essential in the commercial plant tissue culture industry. Cytokinins are also very potent. They are typically used at hundreds of nmoles $1^{-1}$ to tens of $\mu$ moles $1^{-1}$ in tissue culture and endogenous levels in plants exist generally from 1-1000 pmol $\mathrm{gDW}^{-1}$ (Shukla and Sawhney 1992; Arthur et al. 2007). It is well-established that, when combined with auxins, very low cytokinin levels can induce a plant tissue to adopt a range of morphogenic states (Skoog and Miller 1957). Since cytokinins are exceptional mediators of these effects, the low concentrations used in culture can possibly be affected by different preparations of concentrated stock solutions and different storage conditions, potentially shifting morphogenic outcomes and causing variable results.

Plant tissue culture has been affected by irreproducible protocols and aberrant growth since its inception (Gautheret 1983; Thorpe 2006; Bairu and Kane 2011). Though somaclonal variation, a consequence of genetic and epigenetic changes (Larkin and Scowcroft 1981; Kaeppler and Phillips 1993; Tanurdzic et al. 2008; Smulders and De Klerk 2011) has been implicated in growth variability, cytokinins have also been associated with aberrant growth such as shoot-tip necrosis (Bairu et al. 2011) and inhibition of root development in culture (Bollmark and Elisasson 1986). Given that cytokinin solutions are prepared using inconsistent protocols and storage conditions that vary from laboratory to laboratory it is possible that cytokinin instability could be responsible for some variability in plant tissue culture responses. In some cases, cytokinin stability may have a significant impact on the reproducibility of tissue culture protocols as well as commercial production for food crops. Therefore it is important to address the stability profiles of these compounds in solution for dependable use in plant tissue culture research as well as commercial production.

There has been a substantial amount of research studying the metabolic degradation of cytokinins. For reviews see Mok and Mok (2001), Auer (2002), and Sakakibara (2006), and Frébort et al. (2011). However, it is difficult to ascertain or quantify the degradation of adenine-based cytokinins in solution through biological assays because adenine, the main breakdown product, is known to have shoot proliferation and anti-auxin activities (Murashige 1974). Therefore it is useful to characterize the chemical stability of cytokinins in solutions commonly used in plant tissue culture using nonbiological analytical techniques.

There have been reports on the degradation of adeninebased cytokinins in aqueous solution caused by oxidation of
tZ with $\mathrm{KMnO}_{4}$ (van Staden et al. 1982) and peroxidases (van Staden and Forsyth 1985). Yet degradation studies to evaluate cytokinin stability in typical storage conditions have not been published. Furthermore, the stability during autoclaving of some of these cytokinins has been studied (kinetin in Miller et al. 1955; zeatin riboside in Miller 1974), but most references in the literature are anecdotal with respect to their being ( $\mathrm{ZZ}$ and 2iP in Iliev et al. 2010) or not being (BA and kinetin in Panaia et al. 2011) heat-labile. Because of the limited information available on the chemical stability of cytokinins in solution or their physical stability following an autoclave cycle, the present work was undertaken to determine the stability of five widely used adenine-based cytokinins in aqueous solutions: trans-zeatin (tZ), 6- $(\gamma, \gamma$-dimethylallylamino) purine (2iP), kinetin, benzyladenine (BA), and $m$ - topolin.

\section{Materials and Methods}

The adenine-based cytokinins, trans-zeatin (tZ), 6- $(\gamma, \gamma-$ dimethylallylamino) purine (2iP), kinetin, benzyladenine (BA), and $m$-topolin, (PhytoTechnology Laboratories ${ }^{\circledR}$, Overland Park, KS) used in these studies were $>98 \%$ purity. Adenine-free base (PhytoTechnology Laboratories ${ }^{\circledR}$ ) was used as a model to predict behavior of these cytokinins in the analytical assays and was $>99 \%$ purity.

These cytokinins (Fig. 1) were dissolved in solutions containing a final concentration of $0.01-0.5 \mathrm{~N} \mathrm{KOH}$, depending on the cytokinin concentration, solubility, and ability to crystallize. The dissolution process occurred as follows to make a $1.0 \mathrm{mg} \mathrm{mL}^{-1}$ cytokinin solution at $0.05 \mathrm{~N} \mathrm{KOH} ; 1.0 \mathrm{mg}$ of the powder was initially dissolved in $50 \mu \mathrm{L}$ of $1.0 \mathrm{~N} \mathrm{KOH}$, vortexed until no powder was visible, and then brought to a (a)

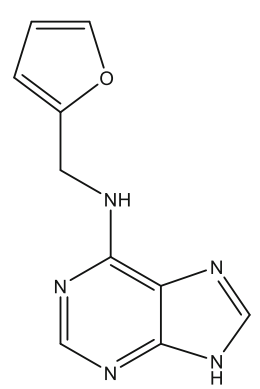

(b)<smiles>c1ccc(CNc2ncnc3[nH]cnc23)cc1</smiles>

(c)<smiles>Oc1cccc(CNc2ncnc3[nH]cnc23)c1</smiles>

(e)

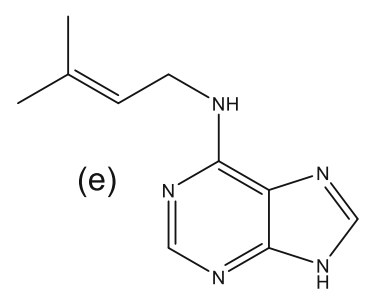

Figure 1. Structure of (a) kinetin, (b) BA, (c) $m$-topolin, (d) tZ, and (e) $2 \mathrm{iP}$. 
final volume of $1 \mathrm{ml}$ with $950 \mu \mathrm{L}$ of deionized water (1$2 \mu \mathrm{S} \mathrm{cm}^{-1}$ ). Degradation studies used $50 \mathrm{mg} \mathrm{mL}^{-1} \mathrm{tZ}$ in $0.5 \mathrm{~N} \mathrm{KOH}$ and storage conditions of $-20,2-6,25,40$, and $75^{\circ} \mathrm{C}$. The other cytokinins were evaluated for stability over $3 \mathrm{mo}$ at $1.0 \mathrm{mg} \mathrm{mL}^{-1}$ in $0.05 \mathrm{~N} \mathrm{KOH}$, except for $\mathrm{tZ}$ which was in $0.01 \mathrm{~N} \mathrm{KOH}$. The acid-based tZ study used $1.0 \mathrm{mg} \mathrm{mL}^{-1} \mathrm{tZ}$ in $0.05 \mathrm{~N} \mathrm{HCl}$. Each sample used for stability analysis was stored in threaded amber glass vials capped with rubber septa and wrapped with teflon tape to minimize evaporation. Subsequent studies with $\mathrm{tZ}$ were performed at $85^{\circ} \mathrm{C}$ in $0.05 \mathrm{~N}$ $\mathrm{KOH}$ and $0.05 \mathrm{~N} \mathrm{HCl}$. Samples were stored at each temperature treatment for $90 \mathrm{~d}$. Trials were performed in triplicate. One-way ANOVA was used to analyze the results obtained for each storage temperature treatment, and the $p$ value is reported when the change is deemed statistically significant $(p<0.05)$.

Samples that were autoclaved were exposed to $121^{\circ} \mathrm{C}$ at $110 \mathrm{kPa}$ for $30 \mathrm{~min}$ in a Sterilmatic STM-EL autoclave (Market Forge Industries, Everett, MA). The total time of exposure to temperatures above room temperature was approximately $1 \mathrm{~h}$. Evaporation loss due to autoclaving was $<10 \%$. The loss for each sample was measured based on the total volume after cooling post-autoclave and was accounted for in the estimation of cytokinin concentration.

\section{ATR-FTIR (fourier transform infrared) spectroscopy} Spectra were obtained with a Spectrum Two FTIR spectrometer (Perkin Elmer, Waltham MA) with a $\mathrm{LiTaO}_{3}$ miniinfrared detector, a single-diamond universal ATR (attenuated-total reflectance) beam accessory, and a pressure arm equipped with a force gauge. The samples were blanked against their respective aqueous solution containing the appropriate concentration of $\mathrm{KOH}$. A 5-20 $\mu \mathrm{l}$ aliquot of sample was placed on the ATR crystal and the spectra were recorded under $75 \mathrm{~N}$ of force. These spectra were recorded from an average of four scans, each with a resolution of $4 \mathrm{~cm}^{-1}$, at a scan speed of $0.2 \mathrm{~cm} \mathrm{~s}^{-1}$, and over the wavenumber range $4000-450 \mathrm{~cm}^{-1}$. Carbon dioxide band suppression was also used.

High pressure liquid chromatography (HPLC) HPLC was performed isocratically for each of the cytokinins with either $40 \%$ methanol (MeOH; for $\mathrm{tZ}$ and $m$-topolin) or $50 \% \mathrm{MeOH}$ (for BA, kinetin, and 2iP) mobile phases at $0.85 \mathrm{~mL} \mathrm{~min}^{-1}$ on a DLC-20 Isocratic Liquid Chromatograph (Cole Parmer, Vernon Hills, IL). The $\mathrm{MeOH}$ used for these studies was ultrapure HPLC grade with $\geq 99.8 \%$ purity (Alfa Aesar, Ward Hill, MA). Mobile phases were either prepared in amber separatefrom-use containers (with a low headspace volume above the liquid interface) or prepared fresh. Whether stored in containers to minimize evaporation or prepared fresh, the mobile phases were used for only $1 \mathrm{mo}$. The column used to resolve these peaks was a 25 -cm-long $(4.6-\mathrm{mm}$-diameter, 5 - $\mu \mathrm{m}$ particles, $100-\AA ̊$ pore size) Kinetex ${ }^{\circledR} \mathrm{C} 18$ column (Phenomenex,
Torrence, CA) equipped with a security guard C18 cartridge. Chromatograms were monitored with UV absorbance at $270 \mathrm{~nm}$. Peaks were isolated through fractionation based on the flow rate and volume of tubing exiting the UV-visible path length. The area under the curve (AUC) was determined to be linear with concentration across all five concentrations tested for each of the cytokinins (Fig. S1). This linearity allows for the concentration to be estimated by taking a proportion of the samples AUC to the initial AUC multiplied by the initial concentration.

Repeated freeze-thaw cycling To investigate the possibility of repeated freeze-thaw loss of $\mathrm{tZ}$, two sets of samples of $\mathrm{t} Z$ at $1.0 \mathrm{mg} \mathrm{mL}^{-1}$ in $0.01 \mathrm{~N} \mathrm{KOH}$ were set up in triplicate to be repeatedly frozen at $-80^{\circ} \mathrm{C}$ and thawed at room temperature every $24 \mathrm{~h}$. Also included were several triplicate control samples (control thaw) that were frozen once at day 0 with one of these samples being thawed and analyzed at every 24 -h interval. The areas obtained from these freeze/thaw samples were normalized against the calibration curve area corresponding to $1.0 \mathrm{mg} \mathrm{mL}^{-1} \mathrm{tZ}(N=6)$ to provide a known outside standard area that was reproducible and not influenced by one single preparation. A single fresh preparation was assayed at 24-h intervals as a positive control.

Mass spectrometry (MS) For each cytokinin, electrospray ionization-mass spectrometry analysis ( ESI-MS) was performed on isolated HPLC peaks from degraded solutions as well as from pure cytokinin solutions. ESI-MS analysis was done on an LTQ linear Ion trap (Thermo Electron, Waltham, MA) with a nanospray source (Proxeon, Waltham, MA) with a picotip emitter (New Objective, Woburn, MA) via a $2 \mu \mathrm{L}$ sample loop (injection rotor) with a continuous infusion flowing at $4 \mu \mathrm{L} \mathrm{min}{ }^{-1}$ (by syringe pump) of an aqueous $10 \%$ methanol, $50 \mathrm{mM}$ acetic acid solution, collecting data in positive ion mode. Acquisitions (ESI-MS or ESI-MS/MS) were made using an optimized tune file generated with $\mathrm{tZ}$ infusion using similar conditions. Absolute detection of adenine and the cytokinins in the LTQ linear ion trap was assessed to verify that peak heights could be compared within spectra (cytokinin versus the adenine degradant peak). Each compound was diluted to a concentration of $100 \mathrm{pmol}_{\mu \mathrm{L}}^{-1}$ and injected as described above. All of these related compounds produced very similar peak heights in the middle of the dynamic range of the ion trap in repetitive runs (data not shown). Therefore, similar conditions were used during the experiments.

\section{Results and Discussion}

Stability Studies with tZ in ATR-FTIR Stability analysis was initially conducted using ATR-FTIR to monitor 

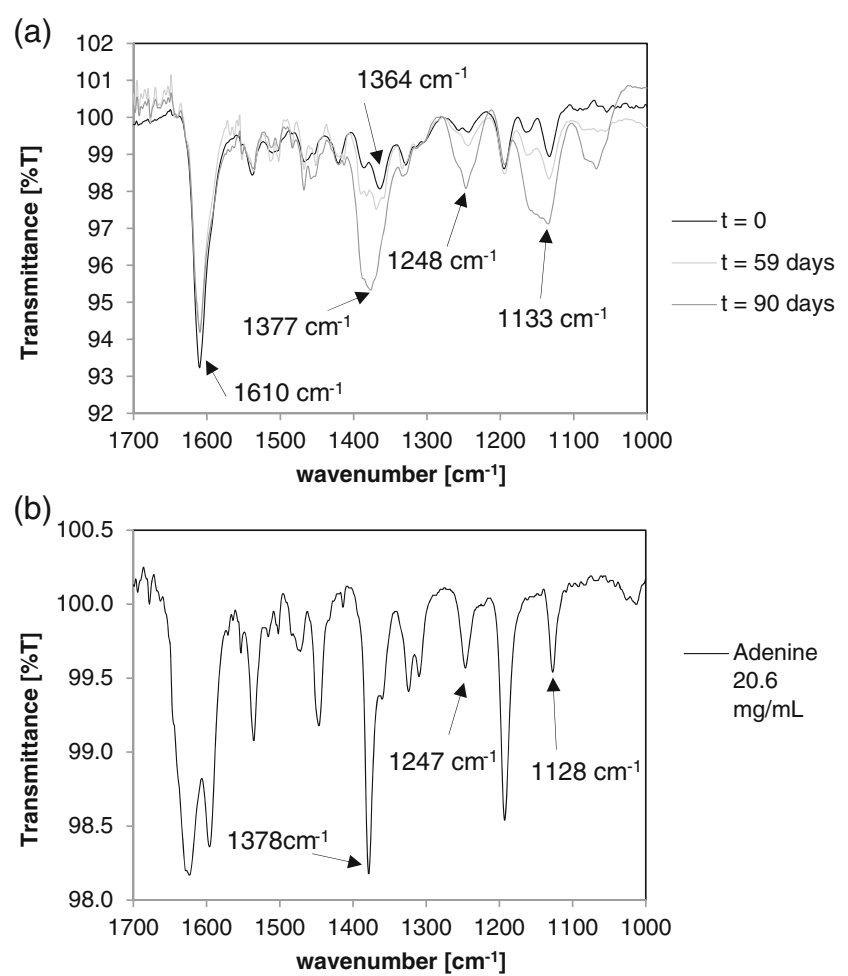

Figure 2. $a$ FTIR spectra of an degradation study of $\mathrm{tZ}$ at $50 \mathrm{mg} \mathrm{mL}^{-1}$ in $0.5 \mathrm{~N} \mathrm{KOH}$ at $40^{\circ} \mathrm{C}$. $b$ Adenine in $0.3 \mathrm{~N} \mathrm{KOH}$ at $20.6 \mathrm{mg} \mathrm{mL}^{-1}$.

degradation since vibrational differences were expected to be found between the parent cytokinin and any degradants. The most intense peak in FTIR for adenine-based cytokinins in aqueous solution occurs at the frequency of $1610 \mathrm{~cm}^{-1}$ (Fig. $2 a$ for tZ). This peak represents the signature of the secondary amines $\mathrm{N}-\mathrm{H}$ movement on adenine. Also shown in
Fig. $2 a$ is change over time at $40^{\circ} \mathrm{C}$ : the $1610 \mathrm{~cm}^{-1}$ peak does slightly decrease with time, but not to the extent that the peak at $1364 \mathrm{~cm}^{-1}$ increases and shifts to $1377 \mathrm{~cm}^{-1}$ with time. Note the increase in peaks 1248 and $1133 \mathrm{~cm}^{-1}$ also in the degradation spectrum.

Adenine is a potential degradant from $\mathrm{tZ}$ after isoprenoid chain scission. Therefore adenine was dissolved in $0.3 \mathrm{~N}$ $\mathrm{KOH}$ at $20.6 \mathrm{mg} \mathrm{mL}^{-1}$ and the FTIR spectrum was recorded (Fig. 2b). The presence of the 1377, 1248, and $1133 \mathrm{~cm}^{-1}$ peaks provide evidence for the possibility of adenine accumulation in the degradation mixture since pure adenine also absorbs at these frequencies (Fig. 2b).

HPLC characterization of parent $t Z$ and degradants in aqueous solution HPLC was employed to quantify the degradation of these compounds because the limit of detection in FTIR-ATR was too high $\left(15 \mathrm{mg} \mathrm{mL}^{-1}\right)$. The typical HPLC chromatogram of pure $\mathrm{tZ}$ has a single peak eluting near $5 \mathrm{~min}$ (Fig. 3a). The only degradant that was seen was a small single peak eluting near 2-2.5 min as shown in Fig. $3 b$. In this instance, the degradant was obtained by incubating tZ in $0.05 \mathrm{~N}$ $\mathrm{KOH}$ at $85^{\circ} \mathrm{C}$ for $48 \mathrm{~d}$. The small solvent peak in these chromatograms had retention times $\left(t_{\mathrm{r}}=2 \mathrm{~min}\right)$ close to that of the degradant. Note the overlap between pure adenine dissolved in $0.05 \mathrm{~N} \mathrm{KOH}$ at $1.0 \mathrm{mg} \mathrm{mL}^{-1}$ eluted near $3.0 \mathrm{~min}$, with the degradant peak near the $2.5 \mathrm{~min}$ (Fig. $3 b$ ). It was difficult to obtain significant amounts of degradant with $\mathrm{tZ}$ in alkaline conditions at $1.0 \mathrm{mg} \mathrm{mL}^{-1}$ in $0.05 \mathrm{~N} \mathrm{KOH}$ in degradation studies (Fig. 3b). Even samples incubated at $85^{\circ} \mathrm{C}$ did not show appreciable degradation after 1 mo relative to degradation with $0.5 \mathrm{~N} \mathrm{KOH}$ exposures at $40^{\circ} \mathrm{C}$ for $90 \mathrm{~d}$ (data not shown).
Figure 3. HPLC chromatogram of (a) standard tZ (1.0 $\mathrm{mg} \mathrm{mL}^{-1}$, $0.05 \mathrm{~N} \mathrm{KOH}),(b)$ overlap of adenine (near $3.0 \mathrm{~min}$ ) with the 2.5 min degradant peak from $\mathrm{tZ}$ incubated at $85^{\circ} \mathrm{C}$ for 48 days, (c) adenine retention time shifting after exposure to $0.05 \mathrm{~N} \mathrm{HCl}$ for 4 min relative to base exposure $(0.05 \mathrm{~N} \mathrm{KOH})$ over the same time period.
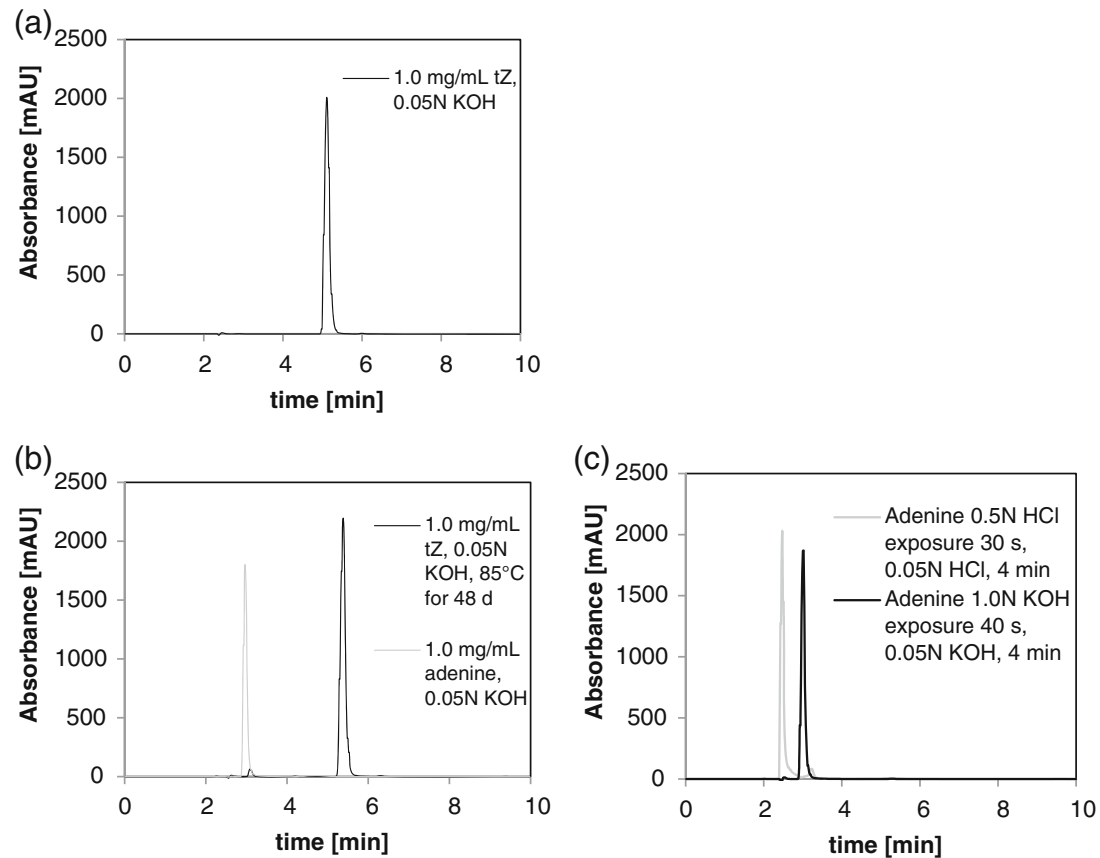
Studies to examine the impact of acid hydrolysis on the adenine ring using preparations of pure adenine at room temperature in $0.05 \mathrm{~N} \mathrm{HCl}$ suggested that degradation occurred in less than 3-4 min, approximately the time necessary to dissolve the powder and inject it onto the column for separation (Fig. 3c). The degraded adenine had an elution peak at $2.5 \mathrm{~min}$, which would correspond to an elution volume of $2.1 \mathrm{~mL}$, and was stable since the absorbance at $270 \mathrm{~nm}$ in HPLC was significant. The result of adenine degrading on such a short time span in a relatively low concentration of acid at room temperature supports the results seen by Lönnberg and Lehikoinen (1982).

\section{Mass spectrometry identification of $\mathbf{t Z}$ and degradants}

Mass spectrometry was used to validate the peak assignments of these degradants obtained by HPLC profiles, and to further characterize these degradants. Following a study of $\mathrm{tZ}$ at $50 \mathrm{mg} \mathrm{mL}^{-1}$ in $0.5 \mathrm{~N} \mathrm{KOH}$ incubated at $75^{\circ} \mathrm{C}$ for $34 \mathrm{~d}, 50 \mu \mathrm{g}$ of $\mathrm{tZ}$ (based on the starting concentration) was injected onto the column and fractionated for mass spectrometry analysis. ESIMS analysis in positive ( + ) ion mode of the isolated peak that eluted at 1.8-3.0 $\mathrm{min}$ (Fig. $3 b$ at $2.5 \mathrm{~min}$ ) revealed adenine as the primary degradation product (peak at $136.16 \mathrm{~m} \mathrm{z}^{-1}$; Fig. 4a), with no $\mathrm{tZ}$ contamination. Polysiloxane $\left(371.1 \mathrm{~m} \mathrm{z}^{-1}\right)$ is a common background ion generated in the loading of the sample.

ESI-MS analysis in positive (+) ion mode of the isolated tZ peak that eluted from 4.0-6.0 min revealed some residual adenine (peak at $136.1 \mathrm{~m} \mathrm{z}^{-1}$ ) (Fig. $4 b$ ) with a sodium adduct of $\mathrm{tZ}$ (peak at $242.1 \mathrm{~m} \mathrm{z}^{-1}$ ). However, the majority of the signal corresponded to $\mathrm{tZ}$ (peak at $220.2 \mathrm{~m} \mathrm{z}^{-1}$ ). A substantial improvement in the resolution of $\mathrm{tZ}$ from adenine could be obtained by lowering both the concentration of the solution and volume injected (data not shown). To further test stability, a typical stock solution of $1.0 \mathrm{mg} \mathrm{mL}^{-1}$ of tZ in $0.05 \mathrm{~N} \mathrm{KOH}$ was stored at $85^{\circ} \mathrm{C}$ for $48 \mathrm{~d}$ and subjected to ESI-MS. A peak eluting at 5.2-5.5 min was observed to contain tZ at nearpurity (peak at $220.25 \mathrm{~m} \mathrm{z}^{-1}$, Fig. $4 c$ ).

To examine the impact of acid dissolution on HPLC peak composition, $\mathrm{tZ}$ was fractionated between 4.7-5.6 min of elution from a $1.0 \mathrm{mg} \mathrm{mL}^{-1} \mathrm{tZ}$ in $0.05 \mathrm{~N} \mathrm{HCl}$ solution that had been stored at room temperature for $56 \mathrm{~d}$. ESI-MS of the isolated fraction showed results that were very similar to Fig. $4 c$ (data not shown). Therefore for either alkaline or acidic dissolution, the peak eluting between 4.6-5.6 min (combining the acid and base overlap of elution) contained only residual adenine degradant.

Since only residual adenine was found in peaks fractionated between 4.6-5.6 min, peaks eluting in this retention time range from pure aqueous solutions of $\mathrm{tZ}$ were used to quantify the amount in solution.

Mass spectrometry of parent cytokinin compounds Chromatographic peaks were isolated for each of the other four cytokinins in the same manner as for tZ. Example mass (a)

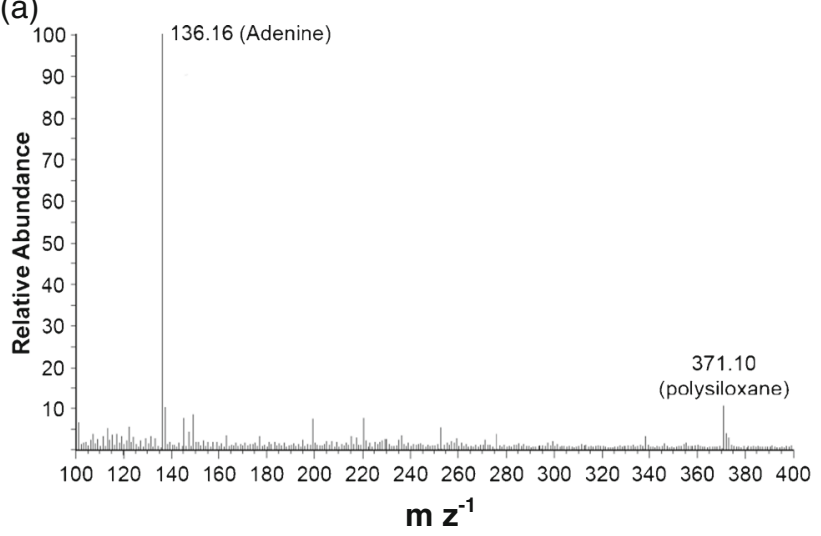

(b)

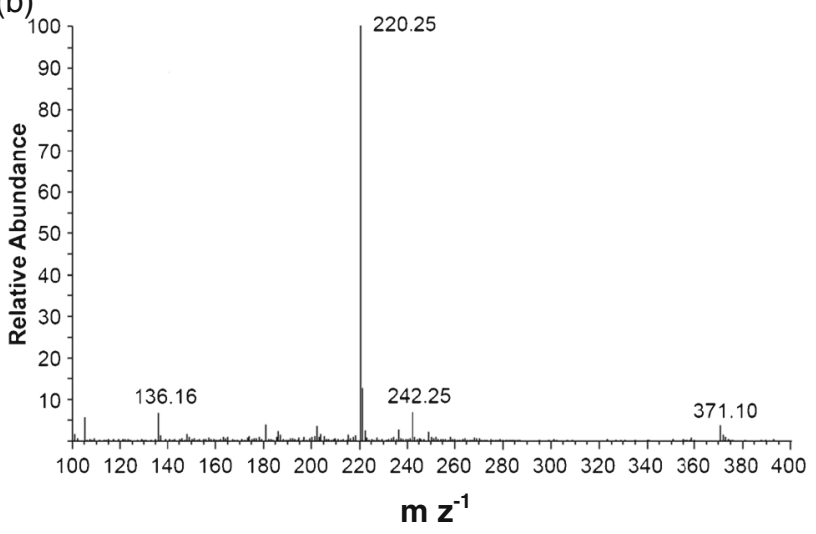

(c)

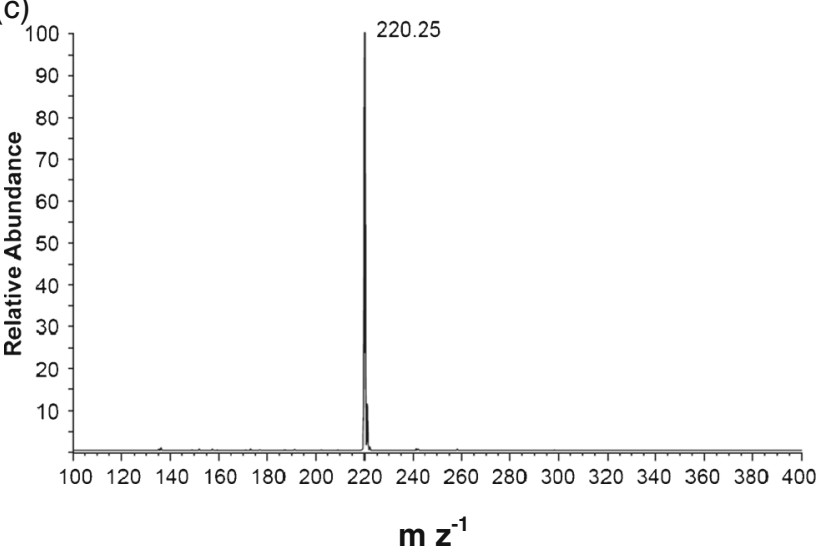

Figure 4. ESI-MS of (a) 1.8-3.0 min HPLC elution in $40 \% \mathrm{MeOH}$ $(136.16 \mathrm{~m} \mathrm{z}-1$ corresponds to adenine $\mathrm{M}+1)$ from $50 \mu \mathrm{g}$ of $\mathrm{tZ}$ in $0.5 \mathrm{~N}$ $\mathrm{KOH},(b)$ 4.0-6.0 min HPLC elution in 40\% MeOH (220.25 m z-1 corresponds to tz $\mathrm{M}+1$ ) from $50 \mu \mathrm{g}$ of $\mathrm{tZ}$ in $0.5 \mathrm{~N} \mathrm{KOH}$, and (c) $5.2-$ $5.5 \mathrm{~min}$ HPLC elution in $40 \% \mathrm{MeOH}(220.25 \mathrm{~m} \mathrm{z}-1$ corresponds to $\mathrm{tZ}$ $\mathrm{M}+1)$ from $2.5 \mu \mathrm{g}$ of $\mathrm{tZ}$ in $0.05 \mathrm{~N} \mathrm{KOH}$.

spectra for each of these cytokinins are shown in supplementary Fig. S2. The apparent near-purity of the fractions obtained provided confidence that the chromatographic peak areas could be used to estimate the degree of degradation. Since the parent cytokinin peak area was also found to behave linearly with concentration, the ratio of the sample cytokinin peak area at and after time zero was the basis for cytokinin stability quantification. 
Figure 5. Stability profiles of trans-zeatin at (a) $50 \mathrm{mg} \mathrm{m}^{-1}$ in $0.5 \mathrm{~N} \mathrm{KOH},(b) 1.0 \mathrm{mg} \mathrm{ml}^{-1}$ in $0.01 \mathrm{~N} \mathrm{KOH},(c)$ Freeze-thaw influence on stability of $\mathrm{tZ}$ at $1.0 \mathrm{mg} \mathrm{ml}^{-1}$ in $0.01 \mathrm{~N} \mathrm{KOH}$, and (d) $1.0 \mathrm{mg} \mathrm{ml}^{-1}$ in $0.05 \mathrm{~N} \mathrm{HCl}_{\text {. }}$

Error bars are plus and minus one standard deviation.
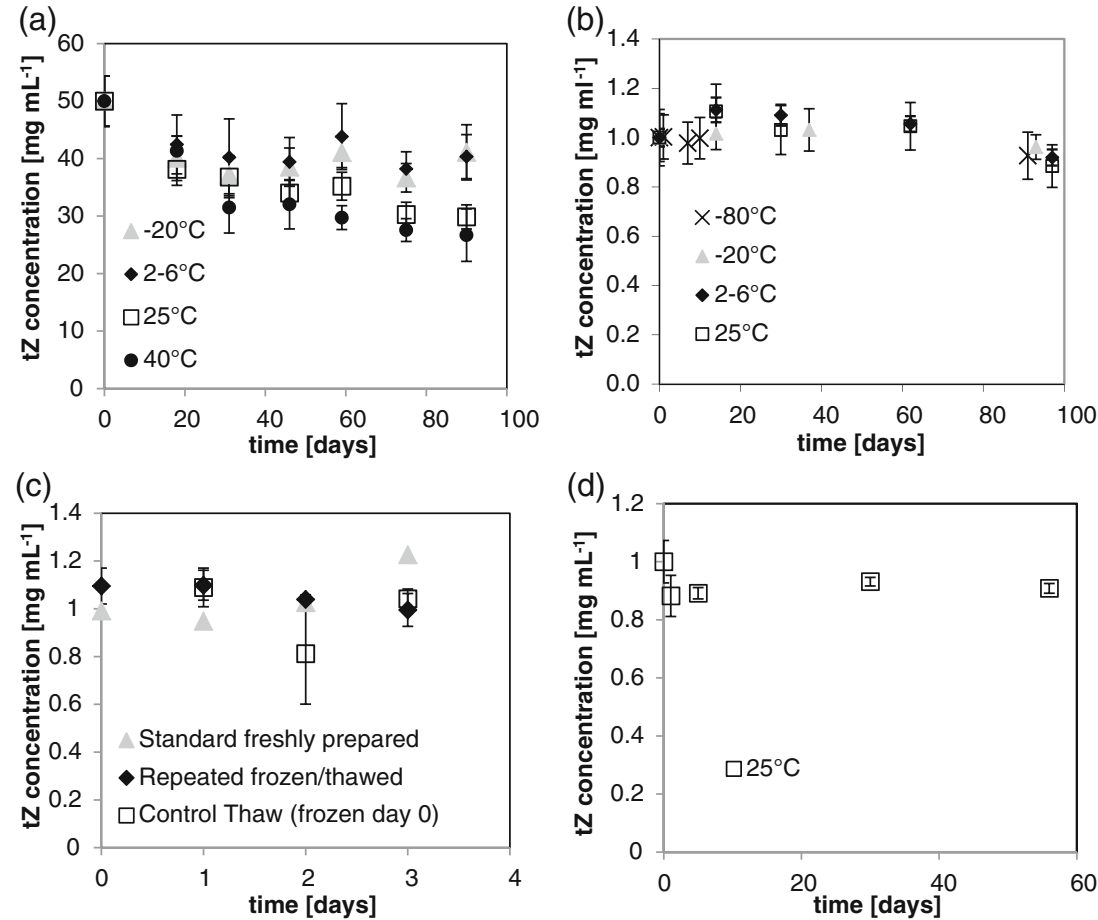

HPLC quantification of the stability of $t Z$ in aqueous solution The peak area analysis for $\mathrm{tZ}$ at $50 \mathrm{mg} \mathrm{mL}^{-1}$ in $0.5 \mathrm{~N} \mathrm{KOH}$ depicts the loss of mass with time at $-20,2-6$, 25 , and $40^{\circ} \mathrm{C}$ (Fig. $5 a$ ). There are two key trends shown in
Fig. $5 a$. First, for each storage temperature treatment, $\mathrm{tZ}$ decayed to approximately $80 \%$ of initial concentration ( $40 \mathrm{mg} \mathrm{mL}{ }^{-1}$ ) after $18 \mathrm{~d}$. Second, $\mathrm{tZ}$ is stable at $-20^{\circ} \mathrm{C}$ : it retained $80 \%\left(40 \mathrm{mg} \mathrm{mL}^{-1}\right)$ of initial concentration through
Figure 6. Stability profiles of $(a)$ $\mathrm{BA}$ at $1.0 \mathrm{mg} \mathrm{mL}^{-1}$ in $0.05 \mathrm{~N}$ $\mathrm{KOH},(b)$ kinetin at $1.0 \mathrm{mg} \mathrm{mL}^{-1}$ in $0.05 \mathrm{~N} \mathrm{KOH},(c) 2 \mathrm{iP}$ at $1.0 \mathrm{mg} \mathrm{mL}^{-1}$ in $0.05 \mathrm{~N} \mathrm{KOH}$, and (d) $m$-topolin at $1.0 \mathrm{mg} \mathrm{mL}^{-1}$ in $0.05 \mathrm{~N} \mathrm{KOH}$. None of the temperatures treatments resulted in statistically significant $(p>0.05)$ concentration change. (a)

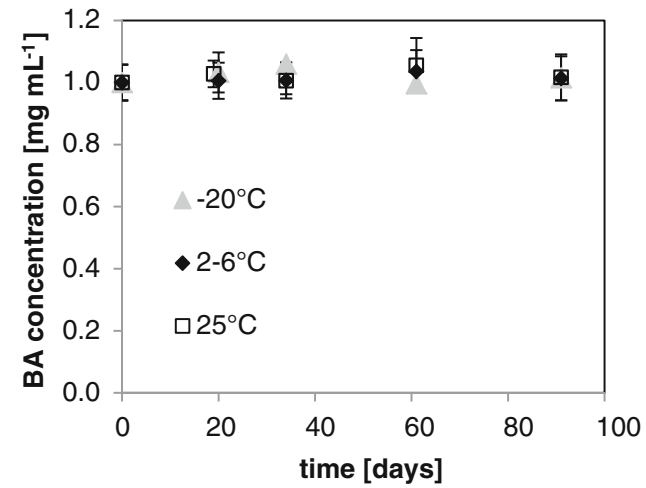

(c)

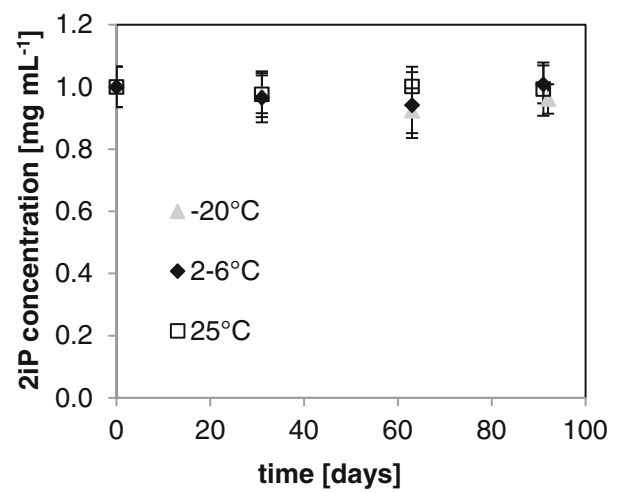

(b)

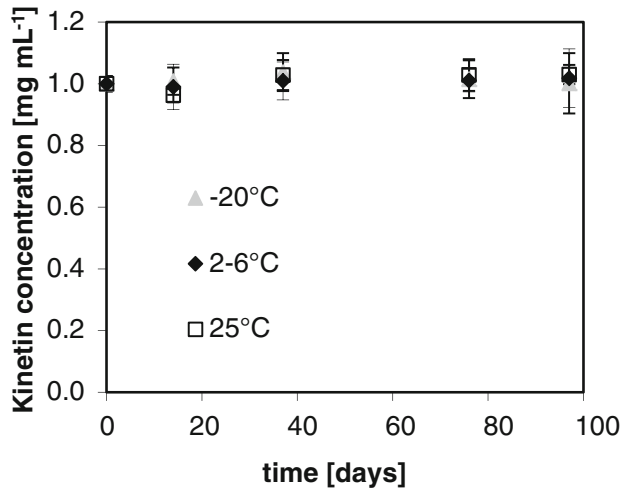

(d)

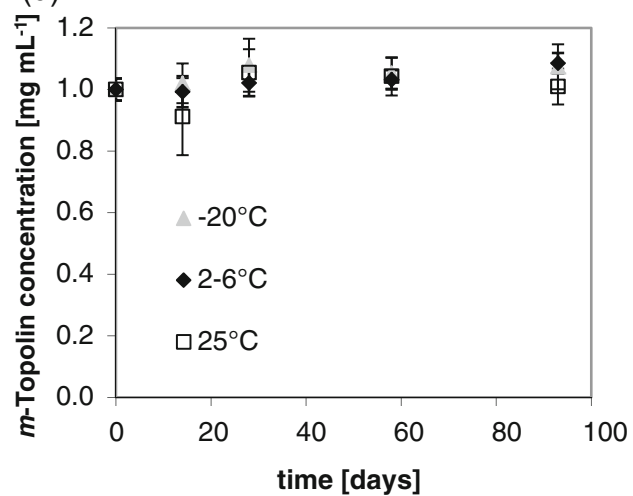


$90 \mathrm{~d}$. Every storage temperature examined over time, except for the $2-6^{\circ} \mathrm{C}$ with $50 \mathrm{mg} \mathrm{mL}^{-1} \mathrm{tZ}$, resulted in highly statistically significant changes in $\mathrm{tZ}$ concentration $(p<0.001,2-$ $\left.6^{\circ} \mathrm{C} p=0.0504\right)$. Solutions of tZ at $50 \mathrm{mg} \mathrm{mL}^{-1}$ in $0.5 \mathrm{~N}$ $\mathrm{KOH}$ lost peak area and thus degraded faster than stock solutions of $1.0 \mathrm{mg} \mathrm{mL}^{-1} \mathrm{tZ}$ and $0.01 \mathrm{~N} \mathrm{KOH} \mathrm{(Fig.} \mathrm{5b).} \mathrm{Though}$ storage at $2-6^{\circ} \mathrm{C}$ of $1.0 \mathrm{mg} \mathrm{mL}^{-1} \mathrm{tZ}$ in $0.01 \mathrm{~N} \mathrm{KOH}$ caused a statistically significant concentration change $(p=0.03)$, storage at other temperatures studied over time did not result in any statistically significant change after $90 \mathrm{~d}$. This is in stark contrast to the results obtained with $50 \mathrm{mg} \mathrm{mL}^{-1}$ tZ in $0.5 \mathrm{~N}$ $\mathrm{KOH}$, and clearly the $\mathrm{tZ}$ solution is most stable when prepared at $1.0 \mathrm{mg} \mathrm{mL}^{-1}$ in $0.01 \mathrm{~N} \mathrm{KOH}$ and stored at lower temperatures.

Since crystallization of BA and kinetin was seen, this required an investigation to rule out any possibility of freezethaw loss not able to be seen with the naked eye. Crystallization required the experiment to be halted because the concentration reported was from the dissolved cytokinin and degradation may be inferred when in fact the cytokinin may not be degraded, just not dissolved. Crystallization of BA and kinetin was sporadic and occurred following autoclaving a solution and storing it at $2-6^{\circ} \mathrm{C}$ before it had cooled to $25^{\circ} \mathrm{C}$, or when samples were cooled to $25^{\circ} \mathrm{C}$ after they were heated significantly above ambient temperature (e.g., $75^{\circ} \mathrm{C}$ ). This suggests the crystallization is a function of cooling rate, and nucleation site availability in the storage containers.

Neither the repeatedly frozen and thawed sample over three freeze-thaws, nor the control thaw showed any statistically significant concentration change over $3 \mathrm{~d}$ (Fig. 5c). From a kinetic point-of-view, the lowest temperature should provide the most stable storage. Therefore, in the absence of any freeze-thaw loss effects, $\mathrm{tZ}$ should be most stable at $-80^{\circ} \mathrm{C}$ at $1.0 \mathrm{mg} \mathrm{mL}^{-1}$ in $0.01 \mathrm{~N} \mathrm{KOH}$.

Even though adenine immediately degraded in $0.05 \mathrm{~N} \mathrm{HCl}$ during the course of sample preparation (3-4 min; Fig. $3 c$ ), tZ was stable in $0.05 \mathrm{~N} \mathrm{HCl}$ for $56 \mathrm{~d}$ at $25^{\circ} \mathrm{C}$ (Fig. $5 d$ ). Nearly all of the $\mathrm{tZ}$ had degraded after storage in $0.05 \mathrm{~N} \mathrm{HCl}$ at $85^{\circ} \mathrm{C}$ for $21 \mathrm{~d}$ (Data not shown), whereas multiple attempts to degrade tZ in $0.05 \mathrm{~N} \mathrm{KOH}$ at $85^{\circ} \mathrm{C}$ for greater than $30 \mathrm{~d}$ left the molecule mostly intact (Fig. 3b).

HPLC quantification of the stability of the adenine-based cytokinins, BA, kinetin, 2iP, and m-topolin Crystallization during storage was less apparent with BA and kinetin when $0.05 \mathrm{~N} \mathrm{KOH}$ was used for $1.0 \mathrm{mg} \mathrm{mL}^{-1}$ even if the cytokinin was initially soluble at $0.01 \mathrm{~N} \mathrm{KOH}$. Consequently, because of the stability of $\mathrm{tZ}$ in alkaline solution at $85^{\circ} \mathrm{C}$, and because of crystallization issues with BA and kinetin in initial studies, $0.05 \mathrm{~N} \mathrm{KOH}$ was used to prepare solutions of BA, kinetin, 2iP, and $m$-topolin $\left(1.0 \mathrm{mg} \mathrm{mL}^{-1}\right)$. Their stability was investigated over $90 \mathrm{~d}$ at storage temperatures of $-20,2-6$, and $25^{\circ} \mathrm{C}$. These are the most commonly used storage temperatures in
Table 1. Summary of adenine-based cytokinin stability in alkaline solution

\begin{tabular}{lllll}
\hline Cytokinin & KOH conc. [N] & \multicolumn{3}{l}{ Stabile $(\geq 90 \%)$ [Y/N], Time [days] } \\
\cline { 3 - 5 } & & $-20^{\circ} \mathrm{C}$ & $2-6^{\circ} \mathrm{C}$ & $25^{\circ} \mathrm{C}$ \\
\hline BA & 0.05 & $\mathrm{Y}, 91$ days & $\mathrm{Y}, 91$ days & $\mathrm{Y}, 91$ days \\
Kinetin & 0.05 & $\mathrm{Y}, 98$ days & $\mathrm{Y}, 98$ days & $\mathrm{Y}, 98$ days \\
$2 \mathrm{iP}$ & 0.05 & $\mathrm{Y}, 92$ days & $\mathrm{Y}, 91$ days & $\mathrm{Y}, 91$ days \\
tZ & 0.01 & $\mathrm{Y}, 93$ days & $\mathrm{Y}, 97$ days & $\mathrm{Y}, 62$ days \\
& 0.50 & $\mathrm{~N}, 18$ days & $\mathrm{N}, 18$ days & $\mathrm{N}, 18$ days \\
$m$-topolin & 0.05 & $\mathrm{Y}, 94$ days & $\mathrm{Y}, 94$ days & $\mathrm{Y}, 94$ days \\
\hline
\end{tabular}

plant tissue culture laboratories. No statistically significant $(p>0.05)$ concentration change was seen over all temperatures for the cytokinins BA, kinetin, 2iP, and $m$-topolin (Fig. 6). It is unknown why, among all of the cytokinins examined, tZ exhibited less stability with concentration changes being statistically significant for the $2-6^{\circ} \mathrm{C}$ at $1.0 \mathrm{mg} \mathrm{mL}$ and $0.01 \mathrm{~N} \mathrm{KOH} \mathrm{(Fig.} \mathrm{5b).} \mathrm{The} \mathrm{statistical} \mathrm{significance} \mathrm{of} \mathrm{this}$ change is not as much as was seen for the $t Z$ degradation in $0.5 \mathrm{~N} \mathrm{KOH} \mathrm{(Fig.} 5 a$ ). Table 1 shows the times and temperatures for each of these cytokinins retaining greater than $90 \%$ of their initial concentration in alkaline solution.

Physical stability of adenine-based cytokinins following one autoclave cycle and with MS salts Stability as affected by high temperatures and pressures, such as those within an autoclave cycle, is also of interest. Solutions of each cytokinin were prepared $\left(1.0 \mathrm{mg} \mathrm{mL}^{-1}, 0.05 \mathrm{~N} \mathrm{KOH}\right.$ in $20 \mathrm{~mL}$ of deionized water) and analyzed via HPLC prior to autoclaving. Post-autoclaving HPLC analysis did not show any peaks representative of degradation (Data not shown), nor were differences in concentrations detected relative to prior to autoclaving (Fig. 7). Since $\mathrm{Z} Z$ was shown as the most unstable of these five cytokinins, its stability was examined in MS-basal salts after one autoclave cycle. There were negligible amounts of

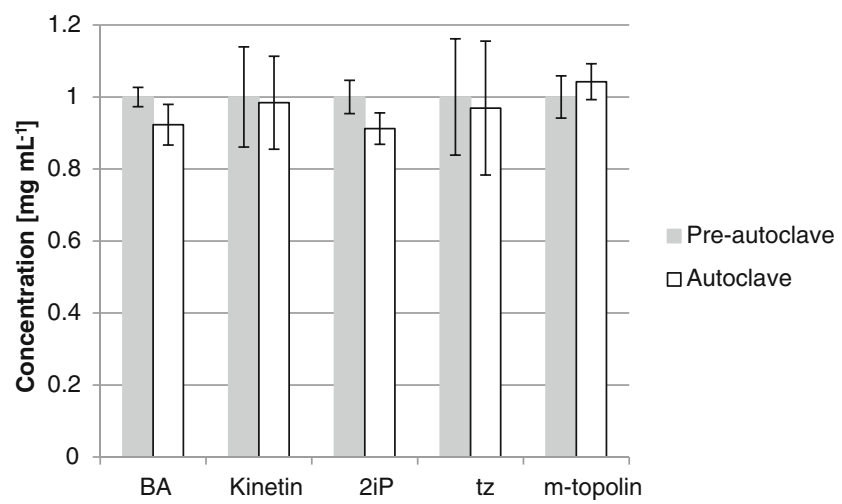

Figure 7. Autoclave stability of each of the cytokinins following one autoclave cycle $\left(121^{\circ} \mathrm{C}, 110 \mathrm{kPa}\right.$ for $\left.30 \mathrm{~min}\right)$. 
degradation of $\mathrm{tZ}$ when dissolved at $10 \mathrm{mg} \mathrm{L}^{-1}$ in standard MS-basal salts.

The data above showed that adenine-based cytokinins dissolved in relatively low base concentrations $(\leq 0.05 \mathrm{~N} \mathrm{KOH})$ are stable in aqueous solutions for $90 \mathrm{~d}$ when stored at $-20,2-$ 6 , or $25^{\circ} \mathrm{C}$. The amount of adenine recovered, based on approximate HPLC peak area relative to the parent $t Z$ peak area, did not correlate with the amount of degraded $t Z$, but this was the only degradant that was identified with ATR-FTIR, HPLC elution volume, and ESI-MS. Based on the loss of peak area and thus absorbance at $270 \mathrm{~nm}$ for $\mathrm{tZ}$ at $0.5 \mathrm{~N} \mathrm{KOH}$, it is suggested that an adenine degradation mechanism resulted in the loss of $20-50 \%$ of the $t Z$ over $90 \mathrm{~d}$. This result is important because it is not uncommon to see plant tissue culture protocols instructing the dissolution of adenine-based cytokinins in $1.0 \mathrm{~N} \mathrm{KOH}$ when as much as $20 \%$ by mass of the tZ can be lost over $18 \mathrm{~d}$ in $0.5 \mathrm{~N} \mathrm{KOH}$.

In $0.05 \mathrm{~N} \mathrm{HCl}$, tZ was stable for $56 \mathrm{~d}$ at $25^{\circ} \mathrm{C}$, yet when pure adenine was dissolved at the same concentration of $\mathrm{HCl}$ at room temperature it degraded in 3-4 min (the time necessary to prepare the sample preparation and inject it into the HPLC column). Trans-zeatin did degrade in the same acid concentration at $85^{\circ} \mathrm{C}$ in $21 \mathrm{~d}$, whereas very little breakdown product was evident from $\mathrm{tZ}$ in $0.05 \mathrm{~N} \mathrm{KOH}$ at $85^{\circ} \mathrm{C}$ for greater than $30 \mathrm{~d}$.

Manufacturers have traditionally considered the natural cytokinins $\mathrm{tZ}$ and $2 \mathrm{iP}$ to be heat-labile and specify storage temperatures of -20 and $2-6^{\circ} \mathrm{C}$, respectively for these dry chemicals often without knowing their stability profiles. Yet plants synthesize natural cytokinins and other growth regulators through late stages of development and sometimes under harsh growing conditions (e.g., $40^{\circ} \mathrm{C}$ field conditions for agriculturally important plants like maize and wheat). While these compounds certainly can display heat-lability (especially when dissolved in $0.5 \mathrm{~N} \mathrm{KOH}$ or $0.05 \mathrm{~N} \mathrm{HCl}$ ), powders stored in dry conditions with low-moisture content are more likely to be stable to the aqueous degradation mechanisms.

Adenine is relatively stable in aqueous solution. The results of autoclaving each of cytokinins showed no statistically significant concentration changes, which is consistent with adenine remaining intact after being exposed to $100^{\circ} \mathrm{C}$ for $1 \mathrm{~h}$ in $0.1 \mathrm{~N}-0.3 \mathrm{~N} \mathrm{NaOH}$ (Jones et al. 1966). Despite previous experience of autoclaving BA for tissue culture, there are only a few references to the physical stability of plant growth regulators in the literature. Perhaps more paradoxically is the noteworthiness of those citations. The first cytokinin discovered, kinetin, was found to become active after autoclaving from herring sperm (Miller et al. 1955). Miller also tested exogenously applied zeatin riboside extracted from crown galls in a soybean-bioassay and found no difference in the results obtained whether sterilization was by autoclaving or filtration (Miller 1974), but did not attempt to quantitate or specifically measure zeatin riboside degradation. Though the ribosyl linkage to adenine may not have held up during autoclaving (Miller 1974), the tZ likely did, which is the basis for its cytokinin activity in the soybean assay. Though there is evidence for adenine-based cytokinin stability in a range of aqueous solution conditions and through one autoclave cycle in a moderately alkaline solution $(0.05 \mathrm{~N} \mathrm{KOH})$, issues with crystallization, and potential adenine degradation under acidic conditions during extreme heating, should provide the user with caution in properly administering these compounds for plant tissue culture. Finally, when transferring tissue culture protocols, the exact powder dissolution method along with storage time and temperature should be considered.

Acknowledgment We wish to thank Professor Michael E. Kane for a critical reading and comments on this manuscript.

Open Access This article is distributed under the terms of the Creative Commons Attribution 4.0 International License (http:// creativecommons.org/licenses/by/4.0/), which permits unrestricted use, distribution, and reproduction in any medium, provided you give appropriate credit to the original author(s) and the source, provide a link to the Creative Commons license, and indicate if changes were made.

\section{References}

Arthur GD, Stirk WA, Novk O, Hekera P, van Standen J (2007) Occurrence of nutrients and plant hormones (cytokinins and IAA) in the water fern Salvinia molesta during growth and composting. Environ Exper Bot 61:137-144

Auer CA (2002) Discoveries and dilemmas concerning cytokinin metabolism. J Plant Growth Regul 21:24-31

Bairu MW, Kane ME (2011) Physiological and developmental problems encountered by in vitro cultured plants. Plant Growth Regul 63:101103

Bairu MW, Novák O, Doležal K, Van Staden J (2011) Changes in endogenous cytokinin profiles in micropropagated Harpagophytum procumbens in relation to shoot-tip necrosis and cytokinin treatment. Plant Growth Regul 63:105-114

Besnard F, Refahi Y, Morin V, Marteaux B, Brunoud G, Chambrier P, Rozier F, Mirabet V, Legrand J, Lainé S, Thévenon E, Farcot E, Cellier C, Das P, Bishopp R, Parcy F, Helariutta Y, Boudaoud A, Godin C, Traas J, Guédon Y, Vernoux T (2014) Cytokinin signaling inhibitory fields provide robustness to phyllotaxis. Nature 505:417421

Bollmark M, Elisasson L (1986) Effects of exogenous cytokinins on root formation in pea cuttings. Physiol Plantarum 68:662-666

Brandstatter I, Kieber JJ (1998) Two genes with similarity to bacterial response regulators are rapidly and specifically induced by cytokinin in Arabidopsis. Plant Cell 10:1009-1019

Frébort I, Kowalska M, Hluska T, Frébortová J, Galuszka P (2011) Evolution of cytokinin biosynthesis and degradation. J Exp Bot 62:2431-2452

Gautheret RJ (1983) Plant tissue culture: a history. Bot Mag Tokyo 96: $393-410$

Hwang I, Sheen J (2001) Two-component circuitry in Arabidopsis cytokinin signal transduction. Nature 413:383-389

Iliev I, Gajdošová A, Liviaková G, Jain SM (2010) Plant micropropagation. In: Davey MR, Anthony P (eds) Plant cell 
culture: essential methods. Wiley-Blackwell, West Sussex, UK, pp $1-24$

Jones AS, Mian AM, Walker RT (1966) The action of alkali on some purines and their derivatives. J Chem Soc C 692-695

Kaeppler SM, Phillips RL (1993) DNA methylation and tissue cultureinduced variation in plants. In Vitro Cell Dev Biol - Plant 29:125130

Kakimoto T (1996) CKI1, a histidine kinase homolog implicated in cytokinin signal transduction. Science 274:982-985

Larkin PJ, Scowcroft WR (1981) Somaclonal variation - a novel source of variability from cell cultures for plant improvement. Theor Appl Genet 60:197-214

Letham DS, Palni LMS (1983) The biosynthesis and metabolism of cytokinins. Annu Rev Plant Physiol Plant Mol Biol 34:163-197

Lönnberg H, Lehikoinen P (1982) Mechanisms for the solvolytic decompositions of nucleoside analogues. X. Acidic hydrolysis of 6 substituted 9-( $\beta$-D-ribofuranosyl) purines. Nuc Acids Res 10: $4339-4349$

Miller CO (1974) Ribosyl-trans-zeatin, a major cytokinin produced by crown gall tumor tissue. Proc Natl Acad Sci U S A 71:334-338

Miller CO, Skoog F, Von Saltza MHV, Strong FM (1955) Kinetin, a cell division factor from deoxyribonucleic acid. J Am Chem Soc 77: 1392

Mok MC, Martin RC, Dobrev PI, Vanková R, Ho PS, YonekuraSakakibara K, Sakakibara H, Mok DWS (2005) Topolins and hydroxylated thidiazuron derivatives are substrates of cytokinin $O$ glucosyltransferase with position specificity related to receptor recognition. Plant Physiol 137:1057-1066

Mok DWS, Mok MC (2001) Cytokinin metabolism and action. Annu Rev Plant Physiol Plant Mol Biol 52:89-118

Murashige T (1974) Plant propagation through tissue culture. Annu Rev Plant Physiol Plant Mol Biol 25:135-166

Panaia M, Bunn E, McComb J (2011) Primary and repetitive secondary somatic embryogenesis of Lepidosperma drummondii (Cyperaceae) and Bloskion tetraphyllum (Restionaceae) for land restoration and horticulture. In Vitro Cell Dev Biol - Plant 47:379-386

Sakakibara H (2006) Cytokinins: activity, biosynthesis, and translocation. Annu Rev Plant Physiol Plant Mol Biol 57:431-449
Shani E, Yanai O, Ori N (2006) The role of hormones in shoot apical meristem function. Curr Opin Plant Biol 9:484-489

Shukla A, Sawhney VK (1992) Cytokinins in a genic male sterile line of Brassica napus. Physiol Plantarum 85:23-29

Skoog F, Armstrong DJ (1970) Cytokinins. Annu Rev Plant Physiol Plant Mol Biol 21:359-384

Skoog F, Miller CO (1957) Chemical regulation of growth and organ formation in plant tissues cultured in vitro. Symposia of the Society for Experimental Biology Number XI. The biological action of growth substances., pp 118-131

Smulders MJM, De Klerk GJ (2011) Epigenetics in plant tissue culture. Plant Growth Regul 63:137-146

Takei K, Sakakibara H, Sugiyama T (2001) Identification of genes encoding adenylate isopentyltransferase, a cytokinin biosynthesis enzyme, in Arabidopsis thaliana. J Biol Chem 276:26405-26410

Takei K, Yamaya T, Sakakibara H (2004) Arabidopsis CYP735A1 and CYP735A2 encode cytokinin hydroxylases that catalyze the biosynthesis of trans-zeatin. J Biol Chem 279:41866-41872

Tanurdzic M, Vaughn MW, Jiang H, Lee TJ, Slotkin RK, Sosinski B, Thompson WF, Doerge R, Martienssen W (2008) Epigenomic consequences of immortalized plant cell suspension culture. PLoS Biol 6(12):e302. doi:10.1371/journal.pbio.0060302

Thorpe TA (2006) History of plant tissue culture. In: Loyola-Vargas VM, Vázquez-Flota F (eds) Methods in molecular biology, plant cell culture protocols, v 318. Human Press, Totowa New Jersey, pp 9-32

Van Staden J, Drewes SE, Hutton MJ (1982) Biological activity of 6-(2,3, 4-trihydroxy-3-methylbutylamino) purine, an oxidation product of zeatin. Physiol Plantarum 55:143-148

Van Staden J, Forsyth C (1985) Peroxidase and zeatin stability. J Plant Physiol 118:367-371

Werner T, Motyka V, Laucou V, Smets R, Van Onckelen H, Schmülling T (2003) Cytokinin-deficient transgenic Arabidopsis plants show multiple developmental alterations indicating opposite functions of cytokinins in the regulation of shoot and root meristem activity. Plant Cell 15:2532-2550

Wickson M, Thimann KV (1958) The antagonism of auxin and kinetin in apical dominance. Physiol Plantarum 11:62-74 